\title{
The Health State of the Students Studying at Kyrgyz-Turkish Manas University
}

\author{
Sabralieva T.M. \\ Kyrgyz-Turkish Manas University \\ Bishkek, Kyrgyzstan \\ tahmira.sabraliyeva@manas.edu.kg
}

\author{
Abdyrakhmanova Dz.O. \\ Kyrgyz-Turkish Manas University \\ Bishkek, Kyrgyzstan \\ jiparkul.abdyrahmanova@manas.edu.kg
}

\author{
Dzhamangulov D.K. \\ Kyrgyz-Turkish Manas University \\ Bishkek, Kyrgyzstan \\ dayir.camangulov@manas.edu.kg
}

\begin{abstract}
Health protection of the student youth is considered to be one of the most important social tasks of the community. The problem of students' health is topical for current period of time, when complicated social and economic conditions are characteristic. Students of higher institutions are future social, economic, intellectual and creative potential of our country. At the same time, students can be classified as a high-risk group, since the difficult age-related problems of modern students are affected by the negative impact of the crisis in almost all the main spheres of society and the state. The purpose of that work is on the basis of medical analysis to identify the level of students health condition studying at KyrgyzTurkish Manas University. On the basis of biochemical blood analysis to identify the number of blood cells, hemoglobin and urine state of the students in the age of 1820 years old. Research methods: biochemical research method; general blood analysis - identification the number of blood cells and hemoglobin; urine analysis determination of the protein and bilirubin in the urine. The study of blood tests at students aged 18-20 years revealed some changes in the number of blood cells and hemoglobin which can lead to different pathologies. There was found a small percentage of protein traces in the urine analysis of 18-20 years students in each age, while the number of bilirubin was within the norms.
\end{abstract}

Keywords—health; erythrocytes; hemoglobin; leukocytes; platelets; protein; bilirubin.

\section{INTRODUCTION}

Health protection of students' youth is one of the most important social tasks of the community. Issues concerning health of the students are especially topical at the time of difficult social and economic conditions. Students of higher institutions are future social, economic, intellectual and creative potential of our country. At the same time, students can be classified as a high-risk group, since the difficult age- related problems of modern students are affected by the negative impact of the crisis in almost all the main spheres of society and the state. Maintaining health and creating a focus on a healthy lifestyle does not always depend on the person himself, first of all, it's necessary to have conditions in which the personality can be formed. In the upbringing of the younger generation, the main emphasis should be made on preventive, physical-health-improving and sports events; forming healthy lifestyle; development of the responsibility for decisions and actions. The key components of the healthy lifestyle are following: rational nutrition, keeping regime of the rest and labour, sufficient sleeping time, daily physical activity, stress resistance.

In current conditions of postindustrial period of state development training of highly qualified specialists in higher institutions is one of the major requisites of successful tasks solution of economic, cultural and social development of the society.

The sociological concepts "healthy lifestyle" and "physical culture" are analyzed in relation to the regional youth community, and ideas about their main components are consolidated.

Methodological basis are resource and risk approaches, in the framework of which youth is considered as a strategic resource of the society. And that society, as well as the speed of society development and social safety degree depends on their health condition. Factors, that motivate to keep healthy lifestyle are: internal position towards the health through realizing values of the life, its endings and necessity of healthy lifestyle for increasing average life expectancy; weak health; labor conditions as a risk for health. The formulated principles of sports and recreational activities system effective functioning in the educational space of the university make it possible to form a universal public request for health resources as an objective factor in the physical, spiritual and social development of youth. 
TABLE I. HEMOGLOBIN AND BLOOD CELLS INDICATORS IN 18-20

Health and healthy lifestyle as fundamental value orientations of future specialists will determine direction of their professional activity, the basis of interaction with the subjects of educational relations, life priorities, attitudes towards people, themselves and worldview positions effect on social activity. Most researches mainly study the negative impact of the crisis in almost all the main areas of society and the state, and the main emphasis is on conducting preventive, recreational and sports events for students. Other part of the research is devoted to forming of healthy lifestyle, rational diet,

compliance with the regime of work and rest, sufficient time for sleep, daily physical activity, stress resistance. However, the level of the heath condition of the students on the basis of medical analysis is not studied enough.

The aim of the paper is on the basis of medical analysis to identify the level of health condition of students studying at Kyrgyz-Turkish Manas University.

The research objectives:

1) On the basis of the blood biochemical analysis to identify the number of blood cells and hemoglobin fo the students at the age 18-20 years.

2) To identify the urine condition of the students at the age 18-20 years.

\section{RESEARCH ORGANIZATION AND METHODOLOGY}

Research organization: the study and health condition evaluation have been conducted in Kyrgyz-Turkish Manas University among freshman students of all departments. 108 students have taken participation, among which 56 youngsters and 52 girls of the age 18-20 years.

Research methods: biochemical methods of the research 1) general blood test - blood cells and hemoglobin number identification; 2) urine analysis - identification of the urine protein and bilirubin.

\section{RESULTS}

The research of blood cells indicators 18-20 years old youngsters has shown that the number of erythrocytes and leukocytes of 18 years' youngsters meets the norms, while the level of hemoglobin is on the bound of norms (130-160 gram/liter), 2 of them have lack of hemoglobin, approximately on $10 \%$ of the norm, and the indicators of 4 students were above the norms. Among 19-years students we could observe, that the erythrocytes' indicators were above the norms on $11 \%$, while the rest 16 students had the indicators within the norms. Only one student has lack of hemoglobin, 6 students are with hemoglobin, that is higher of the norms on $33 \%$. The number of leukocytes and platelets is within the norms except of one, whose number is below the norms. Among 20 years boys the number of blood cells is within the norms, while only three of them have hemoglobin number that is higher the norms. YEARS OLD STUDENTS

\begin{tabular}{|c|c|c|c|c|c|c|}
\hline \multicolumn{7}{|c|}{ YEARS OLD STUDENTS } \\
\hline \multirow[b]{2}{*}{ Age } & Number & Norms & \multicolumn{2}{|c|}{ Erythrocytes } & \multicolumn{2}{|c|}{ Hemoglobin } \\
\hline & $\begin{array}{c}\text { Students } \\
\text { number } \\
\%\end{array}$ & $\begin{array}{c}\text { Students } \\
\text { number\% }\end{array}$ & \multicolumn{2}{|c|}{ Students number\% } & \multicolumn{2}{|c|}{$\begin{array}{l}\text { Students } \\
\text { number\% }\end{array}$} \\
\hline \multirow{3}{*}{18} & \multirow{3}{*}{$\mathrm{n}=20$} & Norm & $20 \%$ & $100 \%$ & $14 \%$ & $70 \%$ \\
\hline & & $\begin{array}{l}\text { Below the } \\
\text { norm }\end{array}$ & - & - & $2 \%$ & $10 \%$ \\
\hline & & $\begin{array}{l}\text { Higher of he } \\
\text { norm }\end{array}$ & - & - & $4 \%$ & $20 \%$ \\
\hline \multirow[b]{3}{*}{19} & \multirow[b]{3}{*}{$\mathrm{n}=18$} & Norm & $16 \%$ & $89 \%$ & $11 \%$ & $61 \%$ \\
\hline & & $\begin{array}{l}\text { Below the } \\
\text { norm }\end{array}$ & -- & -- & $1 \%$ & $6 \%$ \\
\hline & & $\begin{array}{c}\text { Higher of he } \\
\text { norm }\end{array}$ & $2 \%$ & $11 \%$ & $6 \%$ & $33 \%$ \\
\hline \multirow{3}{*}{20} & \multirow{3}{*}{$\mathrm{n}=18$} & Norm & $18 \%$ & $100 \%$ & $15 \%$ & $83 \%$ \\
\hline & & $\begin{array}{l}\text { Below the } \\
\text { norm }\end{array}$ & --- & --- & --- & --- \\
\hline & & $\begin{array}{l}\text { Higher of he } \\
\text { norm }\end{array}$ & --- & --- & $3 \%$ & $17 \%$ \\
\hline
\end{tabular}

\begin{tabular}{|c|c|c|c|c|c|c|}
\hline \multirow[b]{2}{*}{ Age } & Number & Norms & \multirow{2}{*}{\multicolumn{2}{|c|}{$\begin{array}{c}\text { Leukocytes } \\
\text { Students } \\
\text { number } \%\end{array}$}} & \multirow{2}{*}{\multicolumn{2}{|c|}{$\begin{array}{c}\text { Platelets } \\
\text { Students } \\
\text { number\% }\end{array}$}} \\
\hline & $\begin{array}{c}\text { Students } \\
\text { number \% }\end{array}$ & $\begin{array}{l}\text { Students } \\
\text { number\% }\end{array}$ & & & & \\
\hline \multirow{3}{*}{18} & \multirow{3}{*}{$\mathrm{n}=20$} & Norm & $20 \%$ & $100 \%$ & $19 \%$ & $95 \%$ \\
\hline & & $\begin{array}{l}\text { Below the } \\
\text { norm }\end{array}$ & - & - & $1 \%$ & $5 \%$ \\
\hline & & $\begin{array}{l}\text { Higher of he } \\
\text { norm }\end{array}$ & - & - & ---- & ---- \\
\hline \multirow[b]{3}{*}{19} & \multirow[b]{3}{*}{$\mathrm{n}=18$} & Norm & $17 \%$ & $94 \%$ & $17 \%$ & $94 \%$ \\
\hline & & $\begin{array}{l}\text { Below the } \\
\text { norm }\end{array}$ & -- & -- & $1 \%$ & $6 \%$ \\
\hline & & $\begin{array}{l}\text { Higher of he } \\
\text { norm }\end{array}$ & $1 \%$ & $6 \%$ & --- & --- \\
\hline \multirow{3}{*}{20} & \multirow{3}{*}{$\mathrm{n}=18$} & Norm & $18 \%$ & $96 \%$ & $18 \%$ & $83 \%$ \\
\hline & & $\begin{array}{l}\text { Below the } \\
\text { norm }\end{array}$ & --- & --- & --- & --- \\
\hline & & $\begin{array}{l}\text { Higher of he } \\
\text { norm }\end{array}$ & --- & --- & $3 \%$ & $17 \%$ \\
\hline
\end{tabular}

Girls of 18-20 years: among 18-years old - the number of erythrocytes and leukocytes are above the norms on $8 \%$ as well as a one girl's number of the platelets is higher the norm. The number of hemoglobin in 4 girls is below the norms. Among 19-years old the number of erythrocytes in 2 girls is higher the norm while 3 girls' number of leukocytes is higher the norm as well as 9 girls have hemoglobin deficiency (on $31 \%$ ) (table 2). Among 20-years old the decrease of erythrocytes is observable in 3 girls, the hemoglobin decrease is observable in 7 girls and one girl's number of leukocytes is higher the norms. 
TABLE II. HEMOGLOBIN AND BLOOD CELLS INDICATORS IN 18-20 YEARS OLD GIRLS

\begin{tabular}{|c|c|c|c|c|c|c|}
\hline \multirow[b]{2}{*}{ Age } & \multirow{2}{*}{$\begin{array}{c}\text { Number } \\
\text { Students } \\
\text { number } \\
\%\end{array}$} & \multirow[t]{2}{*}{ Norms } & \multicolumn{2}{|c|}{ Erythrocytes } & \multicolumn{2}{|c|}{ Hemoglobin } \\
\hline & & & Amount & $\%$ & Amount & $\%$ \\
\hline \multirow{3}{*}{18} & \multirow{3}{*}{$n=26$} & Norm & 23 & $88 \%$ & 21 & $81 \%$ \\
\hline & & $\begin{array}{l}\text { Below the } \\
\text { norm }\end{array}$ & 1 & $4 \%$ & 4 & $15 \%$ \\
\hline & & $\begin{array}{l}\text { Higher the } \\
\text { norm }\end{array}$ & 2 & $8 \%$ & 1 & $4 \%$ \\
\hline \multirow[b]{3}{*}{19} & \multirow{3}{*}{$n=29$} & Norm & 26 & $90 \%$ & 20 & $69 \%$ \\
\hline & & $\begin{array}{c}\text { Below the } \\
\text { norm }\end{array}$ & 1 & $3 \%$ & 9 & $31 \%$ \\
\hline & & $\begin{array}{l}\text { Higher the } \\
\text { norm }\end{array}$ & 2 & $7 \%$ & -- & -- \\
\hline \multirow{3}{*}{20} & \multirow{3}{*}{$\mathrm{n}=27$} & Norm & 24 & $89 \%$ & 20 & $74 \%$ \\
\hline & & $\begin{array}{c}\text { Below the } \\
\text { norm }\end{array}$ & 3 & $11 \%$ & 7 & $26 \%$ \\
\hline & & $\begin{array}{l}\text { Higher the } \\
\text { norm }\end{array}$ & --- & --- & -- & -- \\
\hline
\end{tabular}

\begin{tabular}{|c|c|c|c|}
\hline \multirow[t]{2}{*}{ Age } & \multirow[t]{2}{*}{ Norms } & \multicolumn{2}{|c|}{ Protein } \\
\hline & & Amount & $\%$ \\
\hline \multirow{2}{*}{$\begin{array}{c}18 \\
\mathrm{n}=26\end{array}$} & Norms & 24 & $92 \%$ \\
\hline & Traces & 2 & $8 \%$ \\
\hline \multirow{2}{*}{$\begin{array}{c}19 \\
\mathrm{n}=29\end{array}$} & Norms & 26 & $90 \%$ \\
\hline & Traces & 3 & $10 \%$ \\
\hline \multirow{2}{*}{$\begin{array}{c}20 \\
\mathrm{n}=27\end{array}$} & Norms & 26 & $96 \%$ \\
\hline & Traces & 1 & $4 \%$ \\
\hline
\end{tabular}

Urine indicators in 18-20 years old students

From the composition of urine, we examined indicators of bilirubin and urine proteins.

The number of urine bilirubin is within the norms among all students. But there are some changes in the number of proteins; there are the traces of protein found. The traces of protein is found among: 4 students of 18 years old, 3 students of 19 years and 1 student of 20 years old.

TABLE III. URINE INDICATORS IN 18-20 YEARS OLD YOUTH

\begin{tabular}{|c|c|c|c|}
\hline Age & Norms & \multicolumn{2}{|c|}{ Protein } \\
\hline \multirow{3}{*}{$\begin{array}{c}18 \\
\mathrm{n}=20\end{array}$} & & Amount & $\%$ \\
\hline & Norms & 16 & $80 \%$ \\
\hline & Traces & 4 & $20 \%$ \\
\hline \multirow{2}{*}{$\begin{array}{c}19 \\
\mathrm{n}=18\end{array}$} & Norms & 15 & $83 \%$ \\
\hline & Traces & 3 & $17 \%$ \\
\hline \multirow{2}{*}{$\begin{array}{c}20 \\
\mathrm{n}=18\end{array}$} & Norms & 17 & $96 \%$ \\
\hline & Traces & 1 & $4 \%$ \\
\hline
\end{tabular}

We observed the traces of protein in 2 girls out of 24 in the age of 18 years, as well as 3 girls of 19 years and one girl of 20 years old. (Tab. \#4)
TABLE IV. URINE INDICATORS IN 18-20 YEARS OLD GIRLS

\begin{tabular}{|c|c|c|c|}
\hline \multirow[t]{2}{*}{ Age } & \multirow[t]{2}{*}{ Norms } & \multicolumn{2}{|c|}{ Protein } \\
\hline & & Amount & $\%$ \\
\hline \multirow{2}{*}{$\begin{array}{c}18 \\
\mathrm{n}=26\end{array}$} & Norms & 24 & $92 \%$ \\
\hline & Traces & 2 & $8 \%$ \\
\hline \multirow{2}{*}{$\begin{array}{c}19 \\
\mathrm{n}=29\end{array}$} & Norms & 26 & $90 \%$ \\
\hline & Traces & 3 & $10 \%$ \\
\hline \multirow{2}{*}{$\begin{array}{c}20 \\
\mathrm{n}=27\end{array}$} & Norms & 26 & $96 \%$ \\
\hline & Traces & 1 & $4 \%$ \\
\hline Age & Norms & \multicolumn{2}{|c|}{ Bilirubin } \\
\hline \multirow{3}{*}{$\begin{array}{c}18 \\
n=26\end{array}$} & & Amount & $\%$ \\
\hline & Norms & 26 & $100 \%$ \\
\hline & Traces & -- & -- \\
\hline \multirow{3}{*}{$\begin{array}{c}19 \\
n=29\end{array}$} & & & \\
\hline & Norms & 29 & $100 \%$ \\
\hline & Traces & -- & -- \\
\hline \multirow{3}{*}{$\begin{array}{c}20 \\
\mathrm{n}=27\end{array}$} & & & \\
\hline & Norms & 27 & $100 \%$ \\
\hline & Traces & -- & -- \\
\hline
\end{tabular}

\section{IV.DISCUSSIONS}

In such a way, research results has shown, that the striking changes of the youth blood analysis are absent. Mainly we can observe the high number of erythrocytes and hemoglobin rather that their decrease. While there is exact opposite situation with the girls, where there is more decrease in the number of hemoglobin and erythrocytes. The decrease in the number of red blood cells and hemoglobin is due to the fact that, by nature, female sex hormones contribute to a decrease in the number of red blood cells. On the contrary, male sex hormones cause an increase in the number of red blood cells (Sabralieva T.M., 2011). Also, a decrease in the concentration of hemoglobin in each red blood cell can be a symptom of iron deficiency anemia, sideroblastic anemia.

An increase in the concentration of hemoglobin in red blood cells is a sign of hyperchromic anemia, an increase in the concentration and content of hemoglobin in the red blood cell are signs of anemia with a deficiency of vitamin B12 or folic acid.

When folic acid is not enough, erythropoiesis is disrupted, less and less red blood cells are maturing, but a certain amount of hemoglobin is needed to maintain satisfactory function of tissue respiration. Therefore, the number of hemoglobin in erythrocytes is high - not only its quantity, but also its concentration is increasing as well. It can be a result of changes in the composition of ions in blood plasma, which leads to wrinkling of red blood cells and a relative increase in hemoglobin concentration.

A decrease in platelet count alone may be a symptom of liver disease. Possible reasons - liver cirrhosis, chronical alcohol intoxication. Decrease in number of all blood cells, platelets as well, low hematocrit - are the symptoms of bone 


\section{References}

marrow hypoplasia. One of the reasons may be taking cytostatics.

A decrease in platelet count may be due to a viral disease, including measles, mumps, and viral hepatitis. In this case, the mechanism of the megakaryocytic germ inhibition is involved. Low number of platelets, an increase in the average number of red blood cells, an increase in the concentration and content of hemoglobin in the red blood cell ar signs of anemia which occurs during the lack of vitamin B12 or folic acid.

A slightly elevated level of leukocytes in the blood may be some time after a meal or exercise.

An increase in the number of leukocytes and platelets indicates an acute inflammatory process in the body.

During viral infections, the total number of leukocytes remains within normal limits or slightly increases. While the percentage of lymphocytes and monocytes increases.

All of the guys and girls in the age of 18-20 years the number of bilirubin in urine is within the norms, and protein traces are found in almost all ages. Protein, even if it is its traces, found in the urine is the cause for concern. Of course, it is not the reason for panic, since this may be a temporary phenomenon having no connection with pathological processes, but also letting go on the brakes isn't recommended as this urinalysis indicator can report serious diseases of the internal organs and even oncology.

\section{CONCLUSION}

1. There are some changes in the form blood elements in 18-20 years old students, which can lead to different pathologies;

2. In urinalysis of the students in the age of 18-20 is found little percentage of protein traces in each age category.
[1] Ulianov D.A., Sovremennaya semiya I zdorovyi obraz zhizni. FKVOT. 2019, vol. 3, p.45.

[2] Grineva E. A., Zakharova L. M., Kolbeneva E. A., Cherkashina V.V. Formation of reproductive health of the younger generation: traditions and innovations.Theory and practice of physical culture. 2019, vol. 3, p.49.

[3] Zheleznyakova S. I., Batyuk L. I., Kornilova I. M. Problems of development of motivation of youth to a healthy lifestyle. Theory and pracitce of physical culture. 2019, vol. 9, p.15.

[4] Gumennyi V.S. Physical education of students of creative specialties. KGADI(HHPI). Kharkov. 2003, vol. 4, 97-104.

[5] Zaytsev V.P. Valueology teaching health. Kharkov: KGIIFK. 1996, p.161.

[6] Sviridova I.A. Medical, social and organizational basis for the formation of health of students. Valeologiya. 2006, vol. 3, pp. 5-11.

[7] Soroka N.F. Nutrition and healthю Minsk: Belarusю 1994, p.350.

[8] Narkhov D.Yu., Vishnevskii Yu.R., Dobrynin I.M., Narkhova E.N. Healthy lifestyle in the views of urban youth of The middle Urals through the 'prism of social bezopasnosti. Theory and practice of physical culture. 2018, vol. 1, pp.9-12.

[9] Tsibulnikov V.E. The nature of the motives of teachers to lead a healthy lifestyle And increase motor activity. FK:VOT, 2018, vol. 5. p. 19;

[10] Sadovnikov E.S. Principles of functioning of the system of sports and recreational activities of youth. Theory and practice of physical culture. 2019, vol. 3, p.75.

[11] Dobrotvorskaya S. G. Organizational and methodological conditions of students ' orientation to a healthy lifestyle. Theory and practice of physical culture. 2016, vol. 9.

[12] Elmurzaev M. A., Panchenko I. A., Pakholkova N.V. Sociopsychological model of health And physical recreation. Theory and practice of physical culture. 2019, vol. 6, p.44;

[13] Shukshina T.I., Akamov V.V., Neyasova I. A., Serikova L.A. Health and healthy lifestyle in the system of value orientations of pedagogical University students. Theory and practice of physical culture. 2019, vol. 6, p.72;

[14] Sabralieva T.M. Physiology of sport: course of lectures. Bishkek:KGAFKiS. 2011, p.143.

[15] Ibraheem T.O., Ajibua M.A., Dominic O.L. Qualification of leisure time physical activity of undergraduate students in South-west, Nigeria. The Russian Journal of Physical Education and Sport. 2018, 13(1), pp. 54-60. DOI: $10 / 14526 / 01 \_2018 \_285$. 